\title{
Sero-Molecular Detection of Toxoplasma Gondii Infection among HIV-Positive Patients in Khartoum : A Cross Sectional Study
}

\author{
Elghazali Mohammed ${ }^{1}$, Mustafa Yassin ${ }^{1}$, Khalid Anan², Awadalkareem Omer², Mutaz A. Elsir2,
} Abdelrahim M. ElHussein ${ }^{2}$, Alamin Abdalkareem¹, Osman Mansour ${ }^{1}$

${ }^{1}$ Parasitology and Medical Entomology department, Medical Laboratory Sciences, El-Neelain University, Sudan ${ }^{2}$ Department of Virology, Central Laboratory, the Ministry of Higher Education and Scientific Research, Sudan

Article Info

Volume 8, Issue 5

Page Number : 125-131

\section{Publication Issue}

September-October-2021

\section{Article History}

Accepted : 10 Sep 2021

Published : 21 Sep 2021

\section{ABSTRACT}

Background and Aim : Toxoplasmosis is one of the most common comorbidities in HIV-positive patients with CD4+ T lymphocytes below 200 cells/ $\mu \mathrm{l}$. Toxoplasmosis with encephalitis may affect HIV infection, in particular in patients with developing AIDS. Early diagnosis and treatment of toxoplasmosis reduces the mortality rate in HIV-positive people. The aim of this study was to estimate the seroprevalence of Toxoplasma gondii infection in HIV-positive patients in Khartoum, Sudan using serological and molecular methods.

Methods : This was a descriptive cross sectional, hospital based study, blood sample were collected from 100 participants; out of them were 50 HIV/AIDS patients and 50 were healthy Blood donors attending HIV Center -Omdurman Hospital, and Sudan Heart Center blood bank respectively. Socio- demographic data were collected by structured questionnaire. Of the 50 HIV/AIDS patients, $25(50 \%)$ were from each gender, their age ranged between 22 and 62 with mean of $39.5+10.69$. They were classified into two age groups; from 22 to 42 years, and from 43 to 62 years, and their distribution was 29 (58\%), and 21 (42\%) respectively. According to the clinical stage they were classified into the four clinical-stage groups and their distribution was as following: $06(12.0 \%)$ in stage 1, $02(04 \%)$ in stage 2, $40(80.0 \%)$ in stage 3, and $02(04.0 \%)$ in stage 4 . Twelve of them (22\%) were under ART treatments. The 50 blood donors on their hand were all males, their age was ranged between 18 and 42 years old. Regarding their educatio, 15 (30\%) were educated, while the remaining 35 (70\%) were none educated. Mentioning their marital status $10(20 \%)$ were married, while 40 (80\%) were single. Regarding the contact with cats 25 (50\%) has contact with cats.

All samples collected were tested for anti-Toxoplasma IgG and IgM antibodies by ELISA, and by PCR for detection of Toxoplasma DNA..

Results: Out of the 50 HIV/AIDS patients; Anti-Toxoplasma IgM was detected 
in two patients (04\%), while IgG was detected in $08(16 \%)$ patients, the Toxoplasma DNA was detected in three (06\%) patients.Regarding the blood donors group; all studied blood donors showed negative results for antitoxoplasma IgM, while 16 (32\%) showed positive anti-Toxoplasma IgG.No blood donors sample was detected positive for Toxoplasma DNA with PCR. There were no significant differences in comparison between the blood donors and the HIV/AIDS patients regarding serological and molecular toxoplasma test results.

Conclusion : The current study showed a relatively high seroprevalance of antiT.gondii IgG and low IgM antibodies in HIV-positive patients in comparison with previous studies in Sudan. Considering the relatively high seroprevalance rate of toxoplasma infection in blood donors reported in this study, toxoplasmosis should be considered as a significant transfusion risk.

\section{INTRODUCTION}

Toxoplasma gondii is an obligate intracellular protozoan parasite that can infect nearly all warmblooded animals including human beings, and can cause serious life-threatening disease in developing fetuses and immunecompromised people ${ }^{(1)}$. Infection is mainly acquired by ingestion of food, water or soil that is contaminated with oocysts shed by cats or by eating undercooked or raw meat containing tissue cysts ${ }^{(2)}$.

Toxoplasmosis is a major public health concern because the disease is serious in terms of mortality or physical and/or psychological sequence in patients with HIV disease (3). In the majority of normal, healthy (immunecompetent) subjects, infection is asymptomatic $(4,5)$ and frequently results in the chronic persistence of cysts within host tissues; the cysts normally lie dormant, probably for life ${ }^{(5)}$. But, the main cause of toxoplasmosis in an HIV patient is the reactivation of latent infection particularly in the brain, leading to toxoplasmic encephalitis (TE), especially when CD4 count reduces to less than 100 cells $/ \mathrm{mm} 3{ }^{(6)}$. Patients with toxoplasmosis and HIV co-infection have 30 to $40 \%$ risk of TE ${ }^{(7)}$. TE may prove to be a fatal infection in HIV patients without receiving appropriate therapy ${ }^{(8)}$.

The prevalence of $\mathrm{T}$. gondii infection in HIV patients varies throughout the world. The overall seroprevalence rate reported is $35.8 \%$ but based on the region it differs from $25.1 \%$ in Asia and the Pacific, $30.1 \%$ in western and central Europe and North America, $44.9 \%$ in sub- Saharan Africa,, $49.1 \%$ in Latin America, to as high as $60.7 \%$ in the Middle East and North Africa (6).

Due to their high sensitivity and specificity, molecular methods are now recognized as an essential diagnostic tool for toxoplasmosis in immunocompromised individuals $(9,10)$. In most developing countries, including Sudan, these methods are not widely used in clinical settings for routine diagnosis and therapeutic management, as they are expensive and time-consuming techniques.

According to different studies, it has been shown that T. gondii can be transmitted through whole blood or leukocyte transfusion and could be alive in citrated blood at $5{ }^{\circ} \mathrm{C}$ for more than 50 days. Accordingly, the refrigeration of blood during storage can't prevent the transfusion- transmission of infection (11). 
Because of the risk of damage in the CNS and high morbidity in HIV-positive individuals, it is important to determine the prevalence of $T$. gondii infection in HIV patients. Consequently, in recent years, detection and monitoring of antiToxoplasma antibodies have become a great concern in HIV-infected patients.Due to limited data on Toxoplasma infection in HIV patients in Sudan, the current study aimed to determine the prevalence of $\mathrm{T}$. gondii antibodies and DNA in this population.

\section{Methods}

This study was a cross sectional, descriptive, hospitalbased study. The subjects of the study were two different groups: 50 HIV/AIDS patients and 50 Blood donor attending HIV Center -Omdurman Hospital, and Sudan Heart Center blood bank, respectively, who were willing to participate in the study. Patients selected were from different areas of the Sudan. A questionnaire including demographic and socioeconomic information was designed to collect baseline data. This study was approved by the central institutional review board, Alneelain University, Khartoum, Sudan. Each patient was informed on the nature of the study and consent was taken from each patient before being enrolled in the study.

Approximately $5 \mathrm{ml}$ of venous blood samples were drawn from each subject, sera were separated by centrifugation and then kept at -20c until used.

\section{Serologic tests:}

The sera was tested for the presence of specific IgM and IgG antibodies to Toxoplasma gondii using an ELISA kit (ChemuxBioScience, INC. USA) according to the manufacturer's instructions.

\section{DNA extraction:}

DNA was obtained by using a commercial DNA extraction kit (intone. Korea) according to the manufacturer's instructions. The purified DNA were dissolved each in $30 \mu$ l elution buffer and stored at $-70^{\circ} \mathrm{C}$ until used.

\section{PCR assay}

A coding region of the GRA6 gene was amplified, with specific forward primer, 5GTAGCGTGCTTGGCGAC-3 and reverse primer, 5ACAAGACATAGAGTGCCCC-3 ${ }^{(23)}$. Amplification was carried out with 10 pmol of each primer and 10 $\mu \mathrm{l}$ of extracted DNA in $20 \mu \mathrm{l}$ of a taq hot start DNA polymerase, Evagreen Master Mix (Biotium, San Francisco, USA) is a 2x master mix, and is supplied with high Rox, low Rox, or no Rox instruments. Amplification was performed using a programmable thermocycler as follows: $5 \mathrm{~min}$ at $95^{\circ} \mathrm{C}$ followed by 35 cycles of 30 seconds at $94^{\circ} \mathrm{C}, 1 \mathrm{~min}$ at $60^{\circ} \mathrm{C}, 2 \mathrm{~min}$ at $72^{\circ} \mathrm{C}$ and a final extension of $72^{\circ} \mathrm{C}$ for $7 \mathrm{~min}^{(23)}$. The PCR products were detected in $1.5 \%$ ethidiumbromide-stained agarose gels.

\section{Results}

Regarding Anti-Toxoplasma IgM was detected in two HIV patients (4\%), while IgG was detected in 8 (16\%) patients while three $(6 \%)$ of the patients were proved DNA positive by PCR.

On the other hand, all studied blood donors showed negative results for anti-Toxoplasma IgM, but 16 (32\%) showed positive anti-Toxoplasma IgG.

No blood donors sample was detected positive for Toxoplasma DNA with PCR.

Comparison between the blood donors and the HIV/AIDS patients groups indicated insignificant differences between the two regarding serological and molecular results ( table 2).

In the blood donors group, no significant association between $\operatorname{IgG}$ prevalence and contact with cats(table $1)$. 
Table 1 : Comparison between Anti-Toxoplasma IgG and contact with cats among 50 blood donors:

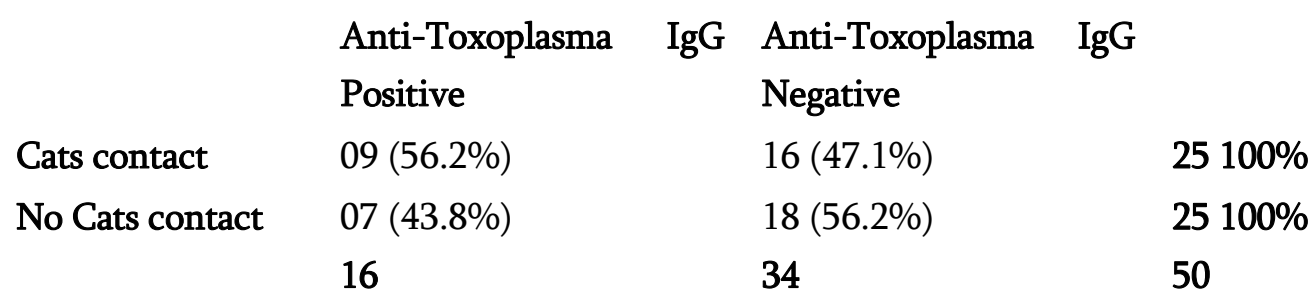

$\mathrm{P}$-value $=0.76176$

Table 2: Distribution of Anti-Toxoplasma IgG/IgM, and Toxoplasma DNA among Blood donors and HIV/AIDS patients.

\begin{tabular}{|c|c|c|c|}
\hline & Blood donor & HIV/AIDS & \\
\hline $\begin{array}{l}\text { Anti-Toxoplasma IgG } \\
\text { Negative }\end{array}$ & $34(68 \%)$ & $43(86 \%)$ & \multirow[t]{2}{*}{$\mathrm{P}$-value $=0.057303$} \\
\hline $\begin{array}{l}\text { Anti-Toxoplasma } \operatorname{IgG} \\
\text { Positive }\end{array}$ & $16(32 \%)$ & $07 \quad(14 \%)$ & \\
\hline $\begin{array}{ll}\text { Anti-Toxoplasma } & \text { IgM } \\
\text { Negative } & \end{array}$ & $50(100 \%)$ & $48(96 \%)$ & \multirow[t]{2}{*}{$\mathrm{P}$-value $=0.15313$} \\
\hline $\begin{array}{l}\text { Anti-Toxoplasma IgM } \\
\text { Positive }\end{array}$ & $00(00 \%)$ & $02(04 \%)$ & \\
\hline $\begin{array}{ll}\text { Toxoplasma } & \text { DNA } \\
\text { Negative } & \end{array}$ & $50(100 \%)$ & $47(94 \%)$ & \multirow[t]{2}{*}{$\mathrm{P}$-value $=0.07864$} \\
\hline $\begin{array}{l}\text { Toxoplasma DNA } \\
\text { Positive }\end{array}$ & $00(00 \%)$ & $03(06 \%)$ & \\
\hline
\end{tabular}

\section{Discussion}

Toxoplasma is worldwide-distributed opportunistic intracellular protozoan parasite, which can cause asymptomatic to life-threatening disease, particularly in immunocompromised individual such as HIV/AIDS $(1,12)$. Presence of organism in blood during the course of infection ensures its transmission through transfusion a fact that was documented since 1971 (13). Moreover, the ability of tachyzoites of toxoplasma organism to survive for several weeks in the stored refrigerated blood is another factor that increases the chance of transmission through transfusion. (14).
In this study, the overall prevalence of anti- $T$. Gondii IgG and IgM antibodies and DNA among 100 study samples was IgG (20\%) HIV patients and (32\%) in blood donors, and DNA (6\%) in HIV patients by PCR. The anti-toxoplasma IgG prevalence in our HIVpositive patients is much lower compared with other countries $^{(1-15)}$,, a high seroprevalence (87.4\%) of antitoxoplasma $\operatorname{IgG}$ antibodies was reported in HIV positive population (16), and in another study from Mozambique ,a prevalence of $31.3 \%$ of IgM indicating recent $\mathrm{T}$-gondii infection by serology was recorded in pregnant HIV-positive women.(22) in addition, studies from Asia, Africa and European countries 
reported prevalence of toxoplasmosis of $30-75 \%$, while in the USA the prevalence was 3-42\%(21)

The prevalence of anti-T. gondii IgG and IgM antibodies in HIV negative blood donors were 32\% and $0.0 \%$, respectively. Seroprevalence of $\operatorname{IgM}$ that we found was semi-comparable to the $2.4 \%$ and $1.9 \%$ reported from Czech Republic and Mexico blood donors, respectively $(17,18)$. The present finding of anti- $T$. gondii IgG antibodies in blood donors is lower than the $75 \%$ prevalence reported from Brazil (20) and 69\% from the Southern Mexican State of Yucatan (19).

According to the present findings, no statistically significant differences were observed among different age groups and inhabitants of rural and urban areas of HIV infected and non-infected study participants, and the associated sero-reactivity of anti- $T$. gondii antibodies. Consumption of undercooked or raw meat was not found to be a risk factor for the presence of anti-T. gondii IgG in HIV negative individuals.while undercooked meat consumption has been found to be an important factor in parasite transmission in several other studies $(21,18)$

The present results showed that $6.0 \%$ of our HIVpositive patients were positive for Toxoplasma gondii DNA, but no DNA was detected in blood donors. There are only few studies reporting PCR result for Toxoplasma gondii in HIV positive patients. Our results may indicate that more studies should be conducted based on more sensitive types of RT-PCR for an accurate diagnosis of acute toxoplasmosis in HIV-positive patients (1).which can greatly reduce transfusion transmission and improve patients management and consequently the disease outcome in these patients.

\section{Conclusion}

The current study showed a relatively high seroprevalance of anti-T.gondii $\operatorname{IgG}$ and low $\operatorname{IgM}$ antibodies in HIV-positive patients if compared to previous studies in the Sudan.

Considering the relatively high seroprevalance rate of toxoplasma infection in blood donors reported in this study, toxoplasmosis should be considered as a significant transfusion risk. Appropriate strategies should be adapted to reduce the risk of acquiring toxoplasmosis through blood transfusion. Regular screening of toxoplasma for early detection of positive anti-T.gondii antibodies are required, while early initiation of therapy is very important to a decrease the mortality rate in patients with HIV/AIDS.

\section{REFERENCES}

[1]. Wang ZD, Wang SC, Liu HH, Ma HY, Li ZY, Wei F, et al. Prevalence and burden of Toxoplasma gondii infection in HIV-infected people: a systematic review and meta-analysis. Lancet HIV. 2017;4(4):e177-e88.

[2]. Fayer R, Dubey JP, Lindsay DS. Zoonotic protozoa: from land to sea. Trends Parasitol. 2004;20(11):531-6.

[3]. Elsheikha HM, Azab MS, Abousamra NK, Rahbar MH, Elghannam DM, Raafat D. Seroprevalence of and risk factors for Toxoplasma gondii antibodies among asymptomatic blood donors in Egypt. Parasitol Res. 2009;104(6):1471-6.

[4]. Studenicova C, Bencaiova G, Holkova R. Seroprevalence of Toxoplasma gondii antibodies in a healthy population from Slovakia. Eur J Intern Med. 2006;17(7):470-3.

[5]. Malla N, Sengupta C, Dubey ML, Sud A, Dutta U. Antigenaemia and antibody response to Toxoplasma gondii in human immunodeficiency virus-infected patients. Br J Biomed Sci. 2005;62(1):19-23.

[6]. Chemoh W, Sawangjaroen N, Siripaitoon P, Andiappan H, Hortiwakul T, Sermwittayawong $\mathrm{N}$, et al. Toxoplasma gondii - Prevalence and Risk Factors in HIV-infected Patients from 
Songklanagarind Hospital, Southern Thailand. Front Microbiol. 2015;6:1304.

[7]. Colombo FA, Vidal JE, Penalva de Oliveira AC, Hernandez AV, Bonasser-Filho F, Nogueira RS, et al. Diagnosis of cerebral toxoplasmosis in AIDS patients in Brazil: importance of molecular and immunological methods using peripheral blood samples. J Clin Microbiol. 2005;43(10):5044-7.

[8]. Daryani A, Sharif M, Meigouni M. Seroprevalence of $\operatorname{IgG}$ and $\operatorname{IgM}$ antiToxoplasma antibodies in HIV/AIDS patients, northern Iran. Asian Pac J Trop Med. 2011;4(4):271-4.

[9]. Okubo Y, Shinozaki M, Yoshizawa S, Nakayama H, Wakayama M, Hatori T, et al. Diagnosis of systemic toxoplasmosis with HIV infection using DNA extracted from paraffinembedded tissue for polymerase chain reaction: a case report. J Med Case Rep. 2010;4:265.

[10]. Julander I, Martin C, Lappalainen M, Guy E, Isberg B, Evengard B. Polymerase chain reaction for diagnosis of cerebral toxoplasmosis in cerebrospinal fluid in HIV-positive patients. Scand J Infect Dis. 2001;33(7):538-41.

[11]. Siegel SE, Lunde MN, Gelderman AH, Halterman RH, Brown JA, Levine AS, et al. Transmission of toxoplasmosis by leukocyte transfusion. Blood. 1971;37(4):388-94.

[12]. Addebbous A, Adarmouch L, TaliA et al. IgG anti-toxoplasma antibodies among asymptomatic HIV-infected patients in Marrakesh- Morocco. Acta Trop. 2012;123(1):49-52.

[13]. Stuart E Siegel, Milford N. Lunde et al. Transmission of toxoplasmosis by leukocyte transfusion. Blood. 1971; 37(4) : 388- 394.

[14]. Yazar S, Eser B \& Yay M. Prevalence of antiToxoplasma gondii antibodies in Turkish blood donors. Ethiop Med J 2006; 44: 257-261.

[15]. Ahmadpour E, DaryaniA, Sharif $M$ et al. Toxoplasmosis in immuno-compromised patients in Iran: A systematic review and metaanalysis. J Infect Dev Ctries. 2014;8(12): 15031510.

[16]. Walle F, Kebede N, Tsegaye $A$ et al. seroprevalence and risk factors for toxoplasmosis in HIV infected and non-infected individuals in Bahir Dar, northwest Ethiopia. Parasite vector. $2013 ;(1): 15$.

[17]. Svobodová V, Literák I. Prevalence of IgM and IgG antibodies to Toxoplasma gondii in blood donors at the Czech republic. Eur J Epidemiol. 1998;14(8):803-805. doi: 10.1023/A:1007589422080.

[18]. Alvarado-Esquivel C, Mercado-Suarez FM, Rodringuez-Briones A, Fallad-Torres L, AyalaAyala OJ, Nevarez-Piedra JL, Duran-Morales E, Estrada-Martinez S, Liessenfeld O, Marquez AJ. Seroepidemiology of infection with Toxoplasma gondii in health blood donors of Durango, Mexico. BMC Infect Dis. 2007; 7:75. doi: 10.1186/1471-2334-7-75.

[19]. Góngora-Biachi RA, Gonzalez Martinez P, Castro-Sansores C, Alvarez-Moguel R, PavíaRuz N, Lara-Perera D, Alonzo-Salomón G, Palacios-Pérez E. Antibodies against Toxoplasma gondii in patients with HIV in Yucatan. Rev Invest Clin. 1998; 50(5):419-22.

[20]. Coelho RA, Kobayashi M, Carvalho J. Prevalence of IgG antibodies specific to Toxoplasma gondii among blood donors in Recife northeast brazil. Rev Inst Med Trop Sao Paulo. 2003;45(4):229-231.

[21]. Montoya JG, Remington JS. In: Principles and practice of infectious diseases. 5. Mandell GE, Beneth JE, Dolin R, editor. Odon: Churchill Livingstone; 2000. Toxoplasma gondii; pp. 2858-2888.

[22]. Jayawardena S, Singh S, Burzyantseva O, Clarke H. Cerebral toxoplasmosis in adult patients with HIV infection. Clin Med J ResidHosp Physician. 2008; 44(7):17-24. 
[23]. Fazacli A, Carter PE, Darde ML, Pennington TH. Molecular typing of toxoplasma gondii strains by GRA 6 gene sequence analysis. Int J parasitol. 2000; 30 (5): 637-42.

\section{Cite this article as:}

Elghazali Mohammed, Mustafa Yassin, Khalid Anan, Awadalkareem Omer, Mutaz A. Elsir, Abdelrahim M. ElHussein, Alamin Abdalkareem, Osman Mansour, "Sero-Molecular Detection of Toxoplasma Gondii Infection among HIV-Positive Patients in Khartoum : A Cross Sectional Study", International Journal of Scientific Research in Science and Technology (IJSRST), Online ISSN : 2395-602X, Print ISSN : 23956011, Volume 8 Issue 5, pp. 125-131, SeptemberOctober 2021. Available at doi : https://doi.org/10.32628/IJSRST218524

Journal URL : https://ijsrst.com/IJSRST218524 